\title{
Main characteristics and genesis of the Vale de Pães skarn (Cuba-Vidigueira, Ossa Morena Zone, Portugal)
}

\section{Principales características y génesis del skarn de Vale de Pães (Cuba-Vidigueira, Ossa Morena Zone, Portugal)}

\author{
R. Salgueiro', C. Inverno ${ }^{2}$, A. Mateus ${ }^{3}$
}

\begin{abstract}
The Vale de Pães (Cuba-Vidigueira) mineralisation is composed of magnetite \pm sulphides and hosted in a Pre-Variscan metamorphic sequence intruded by igneous rocks belonging to the Beja Igneous Complex. Its mineral and chemical features are compatible with a zoned Fe-skarn: Mg-rich (Fo + Digo, oxidised) and Ca-rich (Grs $+D i_{81-39}$, oxidised or relatively reduced). In the Fe-Mg skarn, magnetite deposition occurred along with the anhydrous mineral assemblage at $\approx 600{ }^{\circ} \mathrm{C}$; sulphides precipitated from the retrograde stage onset $\left(\leq 550{ }^{\circ} \mathrm{C}\right)$ and during the hydrated and carbonate phases formation period $\left(<420^{\circ} \mathrm{C}\right)$. In the Fe-Ca skarn, magnetite precipitated during the retrograde stage $\left(<550{ }^{\circ} \mathrm{C}\right)$ together with the hydrated mineral association, and was followed by sulphides at $\approx 400^{\circ} \mathrm{C}$. The mineralising process involved moderate-high salinity fluids and was controlled by variations in redox potential and $\mathrm{pH}$.
\end{abstract}

Key words: Magnetite-sulphide mineralisation, Fe(Mg/Ca) Skarn, Chemical zoning, Ossa Morena Zone.

\section{RESUMEN}

La mineralización del Vale de Pães (Cuba-Vidigueira), compuesta de magnetita \pm sulfuros, se produce dentro de una secuencia metamórfica ante-Varisca intruida por el Complejo Ígneo de Beja (Beja Igneous Complex). Sus características químicas y mineralógicas son consistentes con un skarn de $\mathrm{Fe}$ zonificado: rico en $\mathrm{Mg}\left(\mathrm{Fo}+D i_{\approx 90}\right.$, oxidado) y rico en $\mathrm{Ca}\left(\mathrm{Grs}+D i_{81-39}\right.$, oxidado o relativamente reducido). En el skarn de Fe-Mg, la deposición de magnetita acompaña a la paragénesis mineral anhidra $\left(\approx 600{ }^{\circ} \mathrm{C}\right)$; la precipitación de sulfuros se produce desde el comienzo de la etapa retrógrada $\left(\leq 550{ }^{\circ} \mathrm{C}\right)$ y continuó durante la formación de fases hidratadas y carbonatadas $\left(<420^{\circ} \mathrm{C}\right)$. En el skarn de Fe-Ca, la magnetita se genera en la fase de retroceso $\left(<550^{\circ} \mathrm{C}\right)$, en relación con la asociación de minerales hidratados, seguido de sulfuro $\left(\approx 400^{\circ} \mathrm{C}\right)$. El proceso de mineralización de los fluidos de salinidad moderada-alta era controlado por los cambios en el potencial redox y el $\mathrm{pH}$.

Palabras clave: mineralización de magnetita-sulfuros, Skarn de $\mathrm{Fe}(\mathrm{Mg} / \mathrm{Ca})$, Zonificación química, Zona de Ossa Morena.

\section{Introduction}

The Vale de Pães (Cuba-Vidigueira) mineralisation is part of a set of small ore deposits included in the Magnetite-Zinc Belt of the Ossa-Morena Zone (e.g., Carvalho, 1976, Oliveira 1986). It was recognized during exploration surveys carried out by the
Serviço de Fomento Mineiro (SFM) since 1958. They included geological mapping (1:25000 scale), magnetometry and gravimetry surveys, and 25 drillholes designed to intersect possible mineralised bodies suggested by magnetic anomalies. The hidden Vale de Pães deposit extends in depth up to $180 \mathrm{~m}$ and contains $\approx 9 \mathrm{Mt}$ with average grades of

\footnotetext{
1 Unidade de Investigação de Recursos Minerais e Geofísica, LNEG, Alfragide, Portugal. CeGUL e CREMINER-ISR LA Faculdade de Ciências da Universidade de Lisboa, Portugal. Email: rute.salgueiro@ineti.pt

2 Unidade de Investigação de Recursos Minerais e Geofísica, LNEG, Alfragide, Portugal. CREMINER-ISR LA Faculdade de Ciências da Universidade de Lisboa, Portugal. Email: carlos.inverno@ineti.pt

${ }^{3}$ Departamento de Geologia e CeGUL, Faculdade de Ciências da Universidade de Lisboa, Portugal. Email: amateus@fc.ul.pt
} 
$42 \mathrm{wt} \% \mathrm{Fe}, 19 \mathrm{wt} \% \mathrm{SiO}_{2}$ and 0.6-5.2 wt\% $\mathrm{S}$ (Carvalho, 1976, Oliveira 1986, Carvalho \& Oliveira, 1992). Comprehensive examination of samples collected in one of the drill-holes performed in this area (SD42) allowed to recognise for the first time features that are crucial to the characterisation of these iron ores. The observed mineral assemblages, typical of skarn type deposits, include several calcsilicate minerals, magnetite and sulphides; this deposit typology is likewise compatible with the geological framework in which the Vale de Pães mineralisation developed. The present work intends to report and discuss these data, characterising the mineralised domains and the processes involved in the genesis of the Vale de Pães ore-forming system.

\section{Sampling and analytical procedures}

Representative samples were selected from the SD42 drill-hole core after comprehensive logging. Rock samples were analysed for major elements ( $\mathrm{Si}, \mathrm{Ti}, \mathrm{Al}, \mathrm{Fe}, \mathrm{Mg}, \mathrm{Mn}, \mathrm{Ca}, \mathrm{Na}, \mathrm{K}, \mathrm{P}$ ) and some trace elements (Ba, Rb, S, Sr, Nb, Zr, Y, Sn) by Xray-fluorescence spectrometry (XRF) performed at the ex-Instituto Geológico e Mineiro (IGM) Laboratory (Portugal); they were also analysed for $\mathrm{Au}$ by atomic absorption (AA) and for $\mathrm{Cd}$ and $\mathrm{B}$ by Coupled Plasma-Atomic Emission Spectrometry (DCP-AES) in the same laboratory; the estimated precision analytical errors were usually $<5-10 \%$ for major and trace elements. Complementary analyses were obtained at the Activation Laboratories Ltd (Canada) using the research grade package for $\mathrm{Au}+48$ elements that combines Inductively Coupled Plasma Optical Emission Spectrometry (ICP-OES; including $\mathrm{Ni}, \mathrm{V}, \mathrm{Cu}, \mathrm{Pb}, \mathrm{Zn}, \mathrm{Bi}, \mathrm{Mo}, \mathrm{Be}, \mathrm{Ag}$ ) and Instrumental Neutron Activation Analyses (INAA; including $\mathrm{La}, \mathrm{Ce}, \mathrm{Nd}, \mathrm{Sm}, \mathrm{Eu}, \mathrm{Tb}, \mathrm{Yb}$, Lu Cs, U, Th, $\mathrm{Ta}, \mathrm{Hf}, \mathrm{Cr}$, Co Sc, W, Br, Ir, Au, Hg, As, Se, Sb); in terms of precision, the estimated analytical errors range from $5-10 \%$ on the measured content.

Electron microprobe analyses of pyroxene and olivine were made with a JEOL JCXA 733-CG routinely operated with an acceleration potential of $15 \mathrm{kV}$ and a beam current of $25 \mathrm{nA}$; the different mineral elements were analysed for 20 s each; the analytical quality was controlled through measuring of natural and synthetic mineral standards before, during and after each work period; the analytical errors were less than $2 \%$ for the analysed elements.

\section{Geological setting}

In the Vale de Pães area, different igneous rocks (gabbros, diorites, granites and porphyries) belonging to the Beja Igneous Complex (BIC) intrude a pre-Variscan metamorphic suite containing marbles, amphibolic gneisses, chlorite-rich schists, amphibolites and metavolcanic (quartz-feldspar) rocks (Fig. 1A); contact domains between the two rocksuites are traced by undifferentiated hornfels and amphibolites (e.g., Piçarra et al., 1992). The SD42 drill-hole is located in a contact domain and the recovered drill-hole core reveals a sequence of (volcanic, subvolcanic or intrusive) rocks that were metamorphosed in greenschist to amphibolite facies conditions (Salgueiro, in prep). Meta-felsic intercalations are present from 26 to $166.5 \mathrm{~m}$ depth, the thickest horizon occurring between 160 and $166.5 \mathrm{~m}$ (Fig. 1B). BIC intrusive rocks form different kinds of veins, veinlets and pseudo-intercalations, the main one identified between 185 and $192.04 \mathrm{~m}$ depth; quartz-monzonite $(21.58-22.70$ and $67.80-69.50 \mathrm{~m})$ and granite $(54.21-56.00 \mathrm{~m})$ mineral assemblages appear to dominate in these BIC rocks (Fig. 1B). It is also noteworthy the presence of a meta-dolostone horizon between 178 and $185 \mathrm{~m}$ depth.

\section{Mineralised domains}

Characterisation of representative samples of the SD42 core allowed to distinguish several intervals of disseminated mineralisation with metric thickness, scattered between 86 and $105 \mathrm{~m}$ depth; these intervals include magnetite $(M g t)$ and sulphide-rich (centimetric) bands/levels. Between 105 and $157 \mathrm{~m}$ depth, five intervals of massive $M g t$ ( \pm sulphides) mineralisation with metric thickness occur (106-109 m, 123-128 m, 135-138 m, 142-144 $\mathrm{m}$ and 153-157 $\mathrm{m}$ ), forming intercalations with metamorphic and intrusive rocks (Fig. 1B). Considering the chemical features of the calc-silicate mineral assemblages accompanying the ore-forming phases (presented below) and according to the criteria reported by several authors (e.g., Purtov et al., 1989, Einaudi et al., 1981), representative specimens of disseminated mineralisation are alike of Fe-Ca skarns (e.g., SD42/92, SD42/94, SD42/95 and SD42/98), while those representative of massive mineralisation show strong affinities with Fe-Mg skarns (e.g., SD42/126.3, SD42/155 and SD42/156.46). 

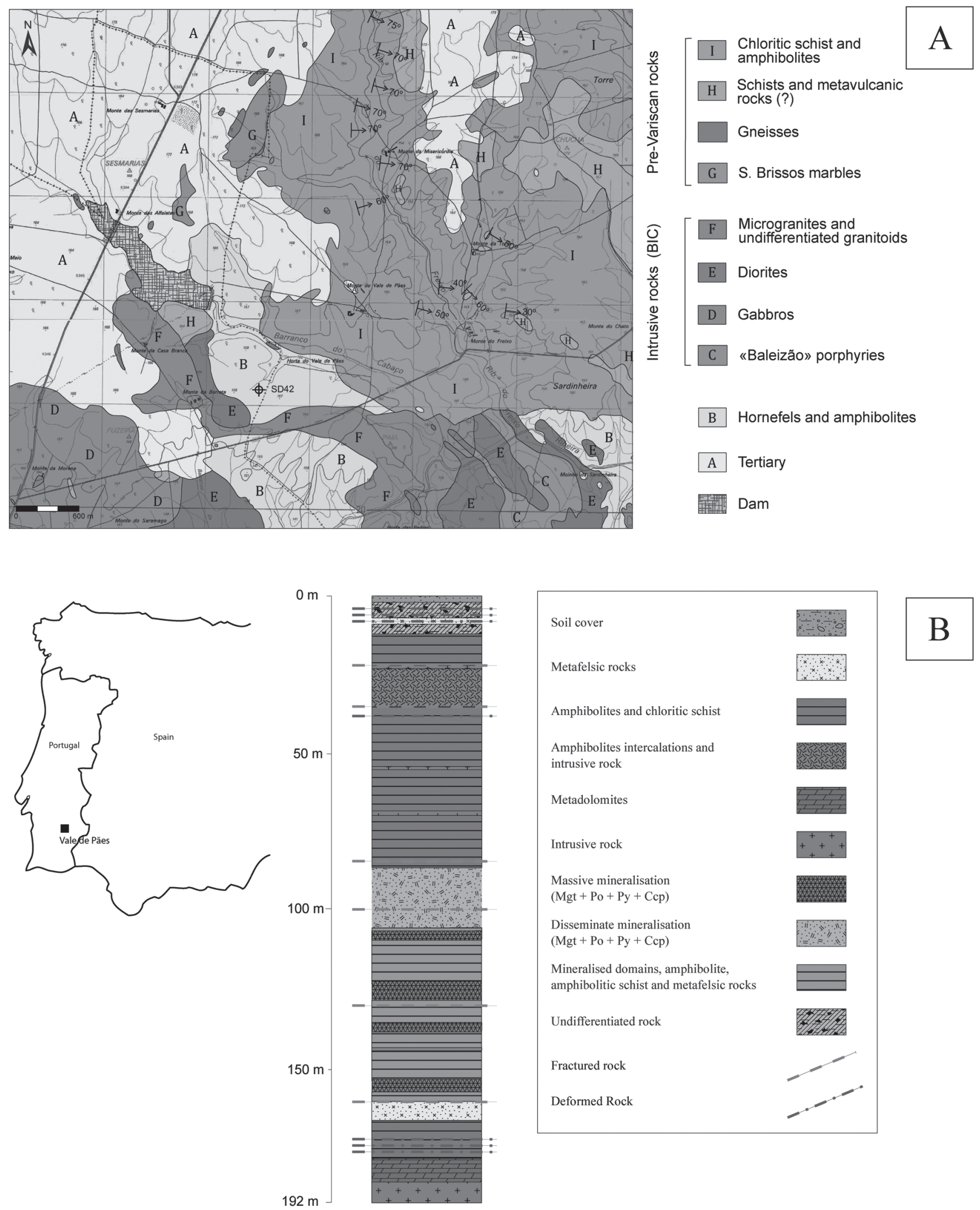

Fig. 1.-A) Geological map of the area surrounding the Vale de Pães deposit (adapted from Serviço de Fomento Mineiro, 1980 approx.) and B) schematic representation of the SD42 drill-hole core log (adapted from Serviço de Fomento Mineiro, 1968). 
Table 1.-Representative analysis of pyroxene and olivine in the Vale de Pães mineralised domains and respective cation distribution per formula unit. Elemental compositions obtained with JEOL JCXA 733-CG electronic microprobe

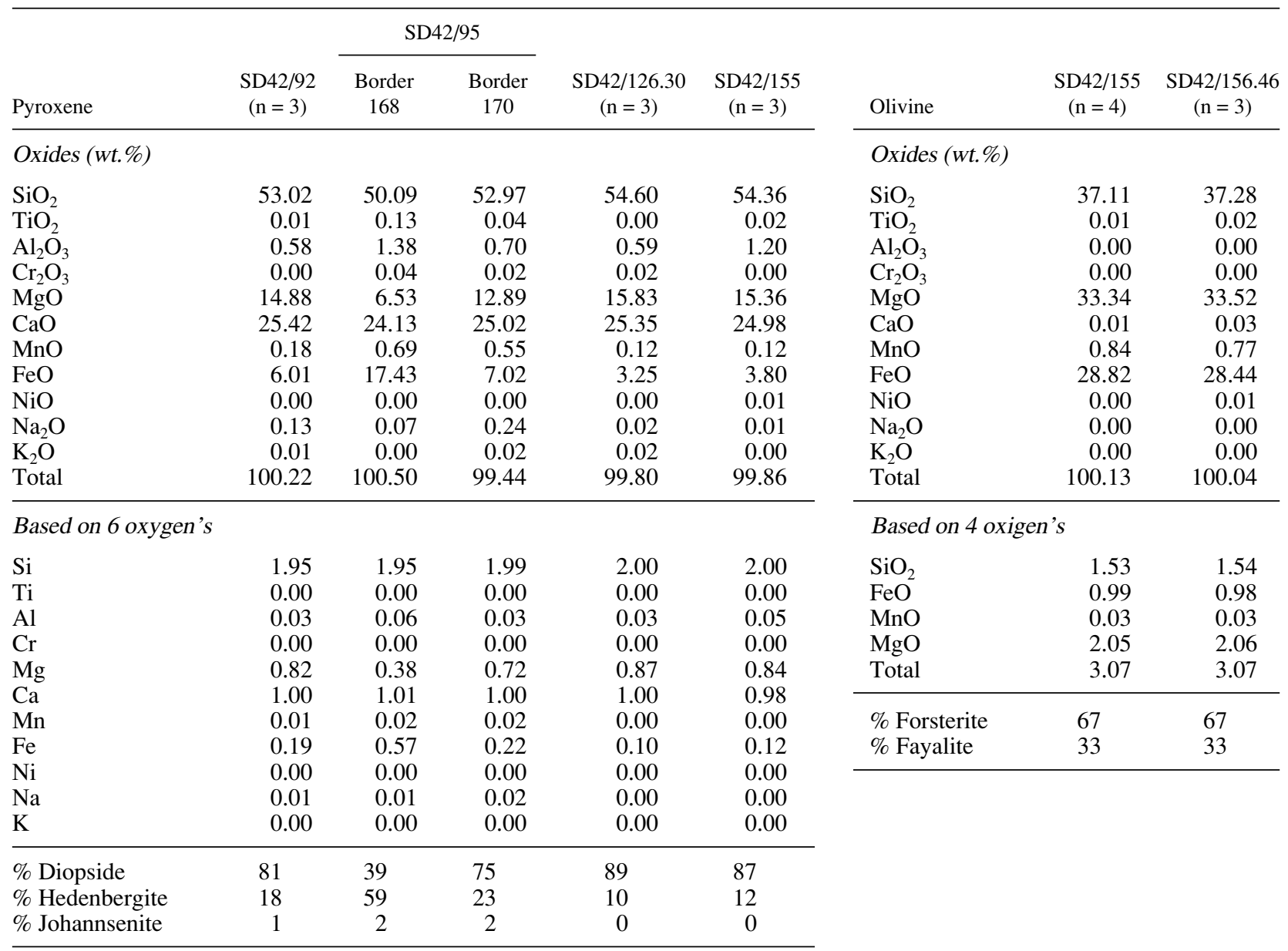

\section{Petrography, mineralogy and relative chronology of deposition}

The Fe-Mg skarn matrix is mostly composed of forsterite $\left(\mathrm{Fo}_{67}\right)$ and diopside $\left(\mathrm{Di}_{\approx 90}\right)$ arranged in a coarse-grained granoblastic texture (Fig. 2A, B and Table 1). These minerals, tracing the prograde stage of skarn development (Fig. 3), are surrounded by Mgt I (predominant) and pyrrhotite (Po) I. Mgt I forms massive but heterogeneously fractured aggregates that include (sub)euhedral grains usually displaying spinel $(S p I)$ exsolutions; its deposition took place during the final steps of the prograde stage. The shallower mineralised domains are characterised by the predominance of massive Mgt showing lesser fracturing, as well as minor re-crystallisation. Po I occurs as massive, irregular, variably fractured aggre- gates, developing complex inter-granular relations with $M g t I$ that suggest close periods of deposition or reflect imbalance/balance conditions established during $M g t I$ re-crystallisation (in the retrograding stage). Po I deposition precedes the development of hydrous phyllosilicates belonging to the serpentine group (Serp), as well as a fracturing event (affecting this sulphide and $M g t I$ ), possibly related to the volume increase in consequence of serpentinisation. Pyrite (Py) I forms, usually, idiomorphic grains and develops textural relationships with other mineral phases of dubious interpretation; nonetheless, it appears to be related to the local early change of $P o$ $I$, further recorded by Py $I I+M g t I I$ exsolutions and, sometimes, marcasite (Mrc). Chalcopyrite (Ccp) I aggregates present very fine granularity and form exsolutions in other sulphides or late replace- 

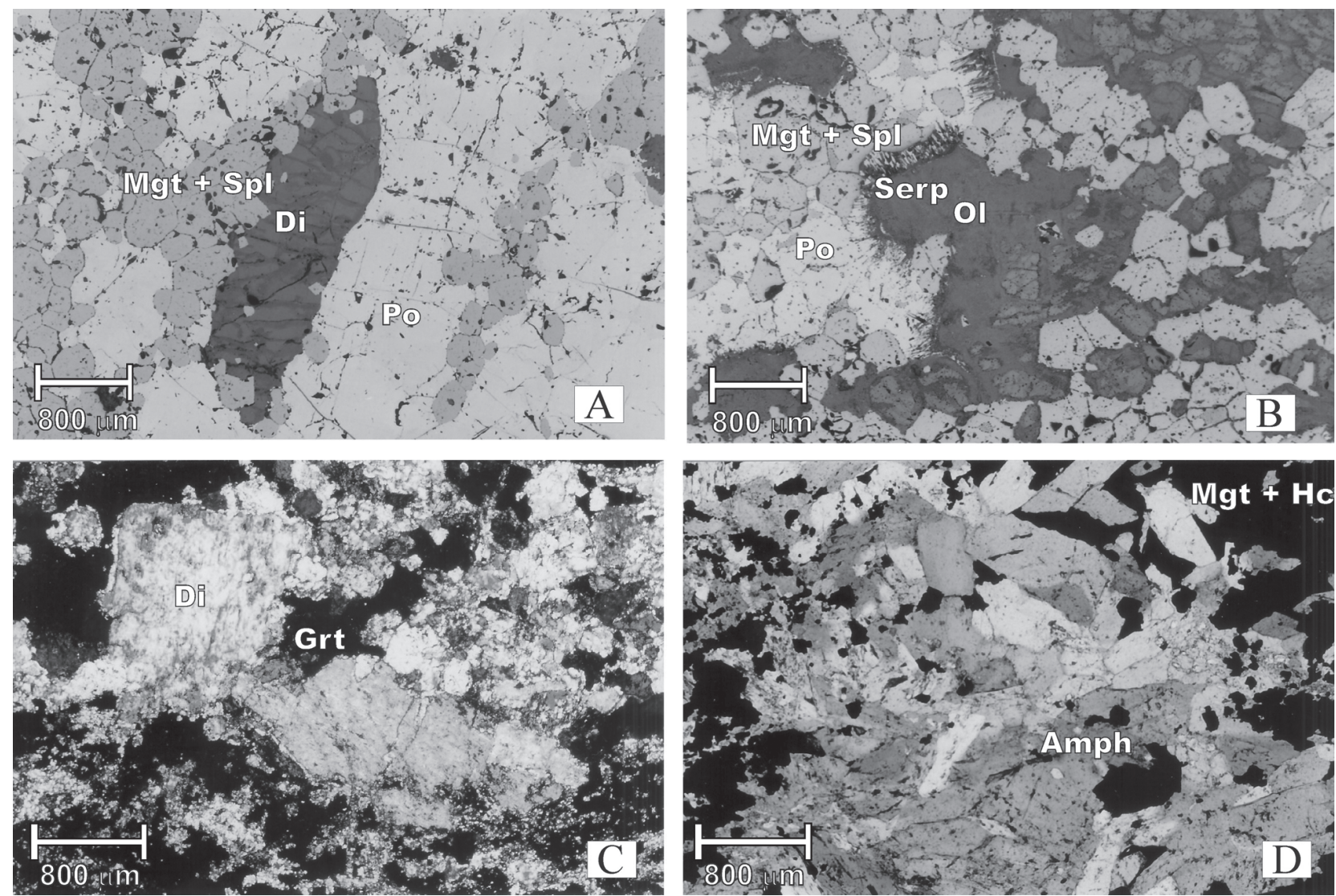

Fig. 2.-Photomicrographs illustrating features of the Vale de Pães mineralisation, A and B) Fe-Mg skarn, C and D) Fe-Ca skarn. A) Di surrounded by $M g t$ (re-crystallised, containing Spl exsolutions) and Po; B) serpentinised Ol encircled by re-crystallised Mgt. C) subhedral grain of $\mathrm{Di}$ and relics of Grt partly replaced by late silicates; D) anhedral grains of Mgt coexisting with late Amph and, sometimes, replacing these silicates. Di: diopside; Mgt: magnetite; Spl: spinel; Hc: Hercynite; Po: Pyrrhotite; Grt: garnet; Amph: amphibole; Ol: olivine; Serp: serpentine.

ments. A carbonatisation event experienced by the Fe-Mg skarn took place after $M g t I$ re-crystallisation, leading to carbonate deposition in veins or differential replacement of the matrix-forming minerals before development of the second generation of sulphides (Py II and Po II). Hydration processes, such as serpentinisation, are synchronous or run shortly after carbonatisation, and play an important role on the heterogeneous replacement of pyroxene and olivine relics; amphibole (Amph) and phlogopite (?), although rare, complete the mineral paragenesis developed during the retrograde stage. The chart in Fig. 3 summarises the paragenetic information concerning the Fe-Mg skarn.

The Fe-Ca skarn matrix is composed of pyroxene and garnet relics (widely replaced by late silicates; Fig. 2C, D) that preserve compositions ranging from diopside $\left(D i_{81}\right)$, salite $\left(D i_{75}\right)$ and ferrosalite $\left(D i_{39}\right)$ (Table 1) and grossularite $\left(G^{2} s_{86} A l m_{12}\right)$. The late mineral assemblages include $\mathrm{mg}$-hastingsite/par-

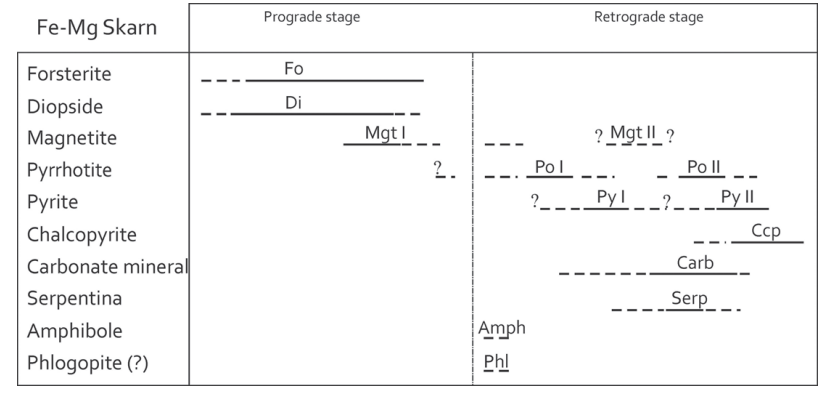

Fig. 3.-Synthesis of the paragenetic information concerning the Vale de Pães Fe-Mg skarn.

gasite, epidote and prehnite, besides rare chlorite, biotite and sphene (Fig. 4). Mgt I is the predominant mineral phase in the irregular and massive ore aggregates; this oxide shows hercynite $(\mathrm{Hc})$ exsolutions and occurs preferentially associated with amphibole and clinopyroxene grains; in places $M g t$ replaces these silicates, reflecting a long-lived peri- 


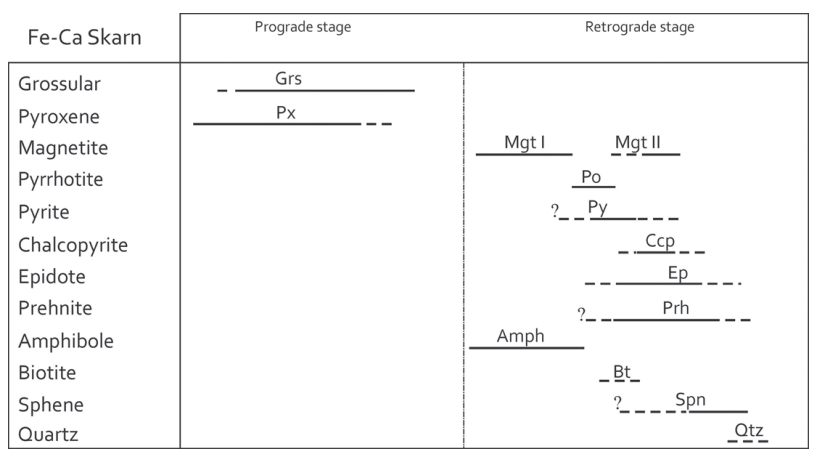

Fig. 4.-Paragenetic information on Vale de Pães Fe-Ca skarn. * Pyroxene composition ranges from diopside to salite/ferrosalite; ** Amphibole composition varies between mg-hastingsite and pargasite.

od of deposition (after deposition of these silicates). Sulphides (Po, Py and Ccp) are scarce and form thin disseminations in matrix. As in the Fe-Mg skarn, the relative chronology of $P y$ deposition is hard to determine, but its relation to $P o$ alteration/replacement is fairly well documented; occasionally, Mrc occurs in equivalent textural context. $C c p$ is very rare and always postdates the remaining sulphides, forming thin exsolutions and replacement rims. Prehnite is a rather late phase, developing aggregates that fill interstitial open spaces. The chart in fig. 4 summarises the paragenetic information available for the Fe-Ca skarn.

\section{Ore geochemistry}

Table 2 presents the analytical results available for key samples. In general and comparatively, $\mathrm{Fe}-$ $\mathrm{Ca}$ skarn samples show, as expected, higher contents of $\mathrm{SiO}_{2}, \mathrm{CaO}, \mathrm{Al}_{2} \mathrm{O}_{3}, \mathrm{Na}_{2} \mathrm{O}, \mathrm{MnO}, \mathrm{TiO}_{2}, \mathrm{La}$, $\mathrm{Ce}, \mathrm{Nd}$ and $\mathrm{Cr}$ than those of $\mathrm{Fe}-\mathrm{Mg}$ skarn; the latter is characterised by higher values of $\mathrm{FeO}(\mathrm{t}), \mathrm{MgO}$, $\mathrm{S}, \mathrm{Cd}, \mathrm{Cu}, \mathrm{Zn}, \mathrm{Co}$ and Ni. The $\mathrm{C} 1$ chondrite (Boynton, 1984) normalised patterns of rare-earth elements (REE), although sub-parallel (Fig. 5A), show different fractionation: $\Sigma$ REE $=90.64$ and $(\mathrm{La} / \mathrm{Yb})_{\mathrm{cn}}$ $=5.84$ for SD42/95 sample; $\Sigma \mathrm{REE}=[15.48,29.21]$ and $(\mathrm{La} / \mathrm{Yb})_{\mathrm{cn}}=[4.31,4.93]$ for the remaining specimens analysed. In sample SD42/95, the Eu normalised value defines a negative anomaly $(\mathrm{Eu} / \mathrm{Sm})_{\mathrm{cn}}$ $=0.6$ ) and possibly the same applies to the remaining samples for which the $\mathrm{Eu}$ content is below the detection limit of the analytical method used. According to Wilde et al. (1996), anomalies in Ce can be put in evidence through the expression: $\log$
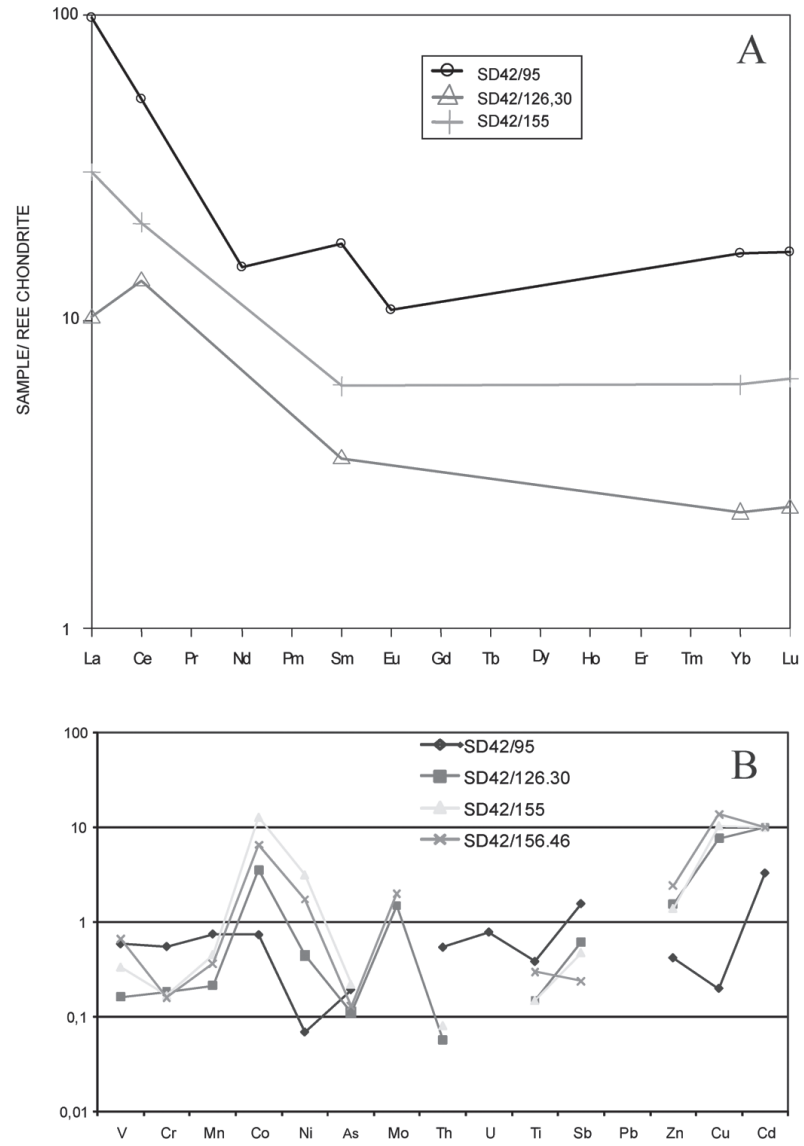

Fig. 5.-A) C1 chondrite (Boynton, 1984) normalised REE patterns. B) RSE and other reference elements normalized patterns (see text for information about the standards used). Samples of the Vale de Pães Fe-Ca (SD42/95) and Fe-Mg skarns (SD42/126.30, SD42/155 and SD42/156.46). Concentrations below the detection limit of the analytical method used were not considered.

$\left[5 \mathrm{Ce}^{*} /\left(4 \mathrm{La}^{*}+\mathrm{Sm}^{*}\right)\right]$, where $*$ refers to $\mathrm{C} 1$ chondrite normalised contents (Boynton, 1984); on this basis, Ce negative anomalies characterise samples SD42/95 and SD42/155 ( -0.19 and -0.08 , respectively), while a positive Ce anomaly stands up for sample SD42/126.3 (0.18).

Contents of some redox sensitive elements (RSE), such as $\mathrm{Cr}, \mathrm{Mn}, \mathrm{Co}, \mathrm{Ni}, \mathrm{As}, \mathrm{Sb}$, Th and U, were normalised to the North American Shale Composite (NASC, Gromet et al., 1984); V values were normalised to the Marine Shale of Ruhr (Degens et al., 1958) and those of Mo to the Recent Sediments (Wedepohl, 1974). Other reference elements, such as $\mathrm{Ti}, \mathrm{Pb}, \mathrm{Zn}, \mathrm{Cu}$ and $\mathrm{Cd}$, were included in this approach, normalising their contents relatively to NASC (Ti) and to Standard Shales (Turekian \& Wedepohl, 1961). Plots of the normalised RSE con- 
Table 2.-Whole-rock analysis of key samples of Vale de Pães Fe-Mg and Fe-Ca skarns

\begin{tabular}{|c|c|c|c|c|c|}
\hline & \multirow[b]{2}{*}{ Method } & \multirow{2}{*}{$\frac{\text { Fe-Ca skarn }}{\text { SD42/95 }}$} & \multicolumn{3}{|c|}{$\mathrm{Fe}-\mathrm{Mg}$ skarn } \\
\hline & & & SD42/126.30* & $\mathrm{SD} 42 / 155$ & SD42/156.46* \\
\hline $\mathrm{SiO}_{2}$ & RXF & 43.14 & 5.6 & 14.32 & 14 \\
\hline $\mathrm{Al}_{2} \mathrm{O}_{3}$ & RXF & 11.46 & tr. & 1.41 & tr. \\
\hline Fe Total (oxides) & RXF & 13.83 & 17.5 & 61.97 & 73 \\
\hline $\mathrm{MnO}$ & $\mathrm{RXF}$ & 0.47 & 0.25 & 0.33 & 0.16 \\
\hline $\mathrm{CaO}$ & RXF & 25.45 & 0.01 & 1.97 & 5 \\
\hline $\mathrm{MgO}$ & RXF & 3.83 & 6 & 11.19 & 6 \\
\hline $\mathrm{Na}_{2} \mathrm{O}$ & RXF & 0.22 & tr. & 0.13 & tr. \\
\hline $\mathrm{K}_{2} \mathrm{O}$ & RXF & $<0.03$ & tr. & 0.04 & 0.04 \\
\hline $\mathrm{TiO}_{2}$ & $\mathrm{RXF}$ & 0.31 & 0.16 & 0.12 & 0.12 \\
\hline $\mathrm{P}_{2} \mathrm{O}_{5}$ & RXF & 0.06 & tr. & $<0.03$ & 0.03 \\
\hline LOI & & 1 & & 3.14 & \\
\hline Total & & 99.77 & 29.52 & 94.62 & 98.35 \\
\hline $\mathrm{S} \%$ & & & 4.93 & 8.46 & 4.17 \\
\hline $\mathrm{S} \%$ & RXF & 0.03 & & & 0.05 \\
\hline $\mathrm{Ba}$ & RXF & $<3$ & $<3$ & $<3$ & $<3$ \\
\hline $\mathrm{Rb}$ & RXF & $<3$ & $<3$ & $<3$ & $<3$ \\
\hline $\mathrm{Sr}$ & RXF & 148 & 15 & 8 & 9 \\
\hline $\mathrm{Cs}$ & INAA & $<1$ & $<1$ & $<1$ & 2 \\
\hline $\mathrm{Ta}$ & INAA & $<0.5$ & $<0.5$ & $<0.5$ & $<0.5$ \\
\hline $\mathrm{Nb}$ & RXF & 10 & 20 & 20 & 21 \\
\hline Hf & INAA & 2 & $<1$ & $<1$ & $<1$ \\
\hline $\mathrm{Zr}$ & RXF & 80 & 28 & 16 & 12 \\
\hline $\mathrm{Y}$ & $\mathrm{RXF}$ & 21 & $<3$ & 7 & $<3$ \\
\hline Th & INAA & 6.7 & 0.7 & 1 & $<0.2$ \\
\hline U & INAA & 2.1 & $<0.5$ & $<0.5$ & $<0.5$ \\
\hline $\mathrm{Cr}$ & INAA & 69 & 23 & 21 & 20 \\
\hline $\mathrm{Ni}$ & $\mathrm{ICP}$ & 3.88 & 25.72 & 183.50 & 101.00 \\
\hline Co & INAA & 19.00 & 92.00 & 327.00 & 169.00 \\
\hline $\mathrm{Sc}$ & INAA & 12.40 & 2.30 & 3.20 & 1.30 \\
\hline $\mathrm{V}$ & ICP & 57.60 & 15.84 & 33.29 & 64.78 \\
\hline $\mathrm{Cu}$ & ICP & 8.96 & 345.03 & 468.18 & 618.40 \\
\hline $\mathrm{Pb}$ & ICP & $<3$ & $<3$ & $<3$ & $<3$ \\
\hline $\mathrm{Zn}$ & ICP & 40.03 & 146.79 & 133.02 & 230.60 \\
\hline $\mathrm{Bi}$ & ICP & $<2$ & 3.22 & $<2$ & $<2$ \\
\hline $\mathrm{Cd}$ & $\mathrm{DCP}$ & 1.00 & 3.00 & 3.00 & 3.00 \\
\hline $\mathrm{Sn}$ & $\mathrm{RXF}$ & $<4$ & $<4$ & $<4$ & $<4$ \\
\hline W & INAA & 2.00 & $<1$ & $<1$ & $<1$ \\
\hline Mo & ICP & $<1$ & 2.84 & $<1$ & 3.60 \\
\hline $\mathrm{Br}$ & INAA & $<0.5$ & $<0.5$ & $<0.5$ & $<0.5$ \\
\hline B & DCP & 26.00 & $<10$ & $<10$ & $<10$ \\
\hline $\mathrm{Be}$ & $\mathrm{ICP}$ & 1.07 & $<1$ & $<1$ & $<1$ \\
\hline $\mathrm{Ag}$ & ICP & $<0.3$ & 0.56 & 0.45 & 0.48 \\
\hline $\operatorname{Ir}(\mathrm{ppb})$ & INAA & $<5$ & $<5$ & $<5$ & $<5$ \\
\hline $\mathrm{Au}(\mathrm{ppb})$ & INAA & $<2$ & $<2$ & 9.00 & $<2$ \\
\hline $\mathrm{Au}(\mathrm{ppb})$ & $\mathrm{AA}$ & 45.00 & 59.00 & 16.00 & 10.00 \\
\hline $\mathrm{Hg}$ & INAA & $<1$ & $<1$ & $<1$ & $<1$ \\
\hline As & INAA & 5.50 & 3.20 & 6.30 & 3.70 \\
\hline $\mathrm{Se}$ & INAA & $<3$ & $<3$ & 5.00 & $<3$ \\
\hline $\mathrm{Sb}$ & INAA & 3.30 & 1.30 & 1.00 & 0.50 \\
\hline $\mathrm{La}$ & INAA & 30.30 & 3.20 & 9.50 & $<0.5$ \\
\hline $\mathrm{Ce}$ & INAA & 43.00 & 11.00 & 17.00 & $<3$ \\
\hline $\mathrm{Nd}$ & INAA & 9.00 & $<5$ & $<5$ & $<5$ \\
\hline $\mathrm{Sm}$ & INAA & 3.50 & 0.70 & 1.20 & $<0.1$ \\
\hline $\mathrm{Eu}$ & INAA & 0.80 & $<0.2$ & $<0.2$ & $<0.2$ \\
\hline $\mathrm{Tb}$ & INAA & $<0.5$ & $<0.5$ & $<0.5$ & $<0.5$ \\
\hline $\mathrm{Yb}$ & INAA & 3.50 & 0.50 & 1.30 & $<0.2$ \\
\hline $\mathrm{Lu}$ & INAA & 0.54 & 0.08 & 0.21 & $<0.05$ \\
\hline
\end{tabular}

Concentrations in wt\% (oxides of major elements) and ppm (minor elements, except when indicated).

* Semi-quantitative analyses of major element oxides. 
tents (Fig. 5B) show sub-parallel patterns for samples representing the Fe-Mg skarn (SD42/155 and SD42/156.46), which differ from the one concerning the Fe-Ca skarn (SD42/95). Note that RSE contents in the latter sample are almost always below the respective standard, highlighting only positive anomalies in $\mathrm{Sb}$ and $\mathrm{Cd}$, in addition to a clear depletion in $\mathrm{Ni}$ and $\mathrm{Cu}$ values. In contrast, the RSE normalised patterns for samples of $\mathrm{Fe}-\mathrm{Mg}$ skarn show pronounced positive anomalies for Co, Mo, $\mathrm{Ni}, \mathrm{Zn}, \mathrm{Cu}$, and $\mathrm{Cd}$, denoting significant enrichment relatively to the standard used; the Th and As contents are very low, showing well-marked negative anomalies. The contents of $\mathrm{Mn}$ are negligible in all samples of the mineralised domains.

\section{Discussion}

Considering the matrix-forming minerals present in mineralised domains, critical information can be inferred by considering the oxidation state reflected by mineral paragenesis developed in the prograde stage (Einaudi et al., 1981, Einaudi \& Burt, 1982). Indeed, according to Newberry (1983), the compositions displayed by the grossularite relics in the Vale de Pães Fe-Ca skarn (SD42/95) correspond to those generated in equilibrium with reducing fluids. Additionally, the analysed pyroxenes show significant oscillation in hedenbergitic contents, besides their tendency to increase in the Fe-Ca skarn domains; in the latter, $\mathrm{Di}_{39}$ compositions are known in sample SD42/95, suggesting further media reduction (e.g., Einaudi et al., 1981). The mineral paragenesis tracing the final step of the prograde stage experienced by the Fe-Mg skarn $\left(F o+D i_{z 90}+M g t\right)$, suggests that the upper limit of $a\left(\mathrm{O}_{2}\right)$ was closer to that ruled by the $M g t / \mathrm{Hem}$ buffer. In transition to the retrograde stage, redox media conditions and $\mathrm{Fe}$ availability allowed the precipitation of sulphides (Po I and Py I?, which persisted after the carbonisation process), favouring the development of $\mathrm{Mgt}-\mathrm{Hc}$ exolutions as well. The redox conditions at this stage were also enough to cause the instability of olivine, leading to the generation of phyllosilicates (serpentine group) and $\mathrm{Mgt} I I$. The presence of Fe oxides in late veins indicates that $a\left(\mathrm{O}_{2}\right)$ conditions near the buffer $\mathrm{Hem} / \mathrm{Mgt}$ were achieved during the final steps of the retrograde stage.

The distribution of RSE contents testifies enrichments in $\mathrm{Cu}, \mathrm{Cd}, \mathrm{Zn}, \mathrm{Co}, \mathrm{Ni}$ and Mo (Fig. 5B), consistent with an increase of sulphides (particularly abundant in the Fe-Mg skarn), also agreeing with the prevalence of reducing conditions during the retrograde stage.

The incipient Mn enrichment (a minor component in $\mathrm{Mgt}$ and $\mathrm{SpI}$ ) is interpreted as reflecting the limited availability of this metal, determined by the original concentration in protolith and/or influenced by its solubility in metasomatic fluids. In fact, the differential mobility of chemical elements is a determinant factor for chemical zoning of many mineralising systems (including those of skarn type) and, in the case of $\mathrm{Mn}$, the enrichment trend is focused on domains far from the source magma (Meinert, 1992, 1997). According to the available data, Mn contents are higher in Fe-Ca skarn intervals [incorporated in pyroxenes (Table 1) and in Mgt, Salgueiro, in prep.], hence suggesting the possibility of a position further away from the magmatic source compared to the Fe-Mg skarn position; this inference must be, however, unequivocally demonstrated with comprehensive analytical studies.

Pyroxenes in the Vale de Pães Fe-Mg skarn are mainly diopsidic $\left(D i_{\approx 90}\right)$ and show $\mathrm{Al}_{2} \mathrm{O}_{3}$ contents (average $\approx 1: 00 \mathrm{wt} \%$ ) similar to specimens that are typical of magmatic skarns according to Zharikov (1970). However, the fayalitic component of the olivine included in the (anhydrous) prograde mineral paragenesis $\left(\mathrm{Fa}_{33}\right)$ is significantly above the values reported by Zharikov (1970) for olivines in those magmatic skarns (i.e., $F a_{5-15}$ ). These data, taken together with the period of $M g t$ precipitation, can be interpreted as a consequence of the compositional characteristics of the magmatic component involved in the prograde stage, which is consistent with the possibility of placing the Fe-Mg skarn near the magma source. Based on experimental data for the Fo + Di $+S p l$ equilibrium (e.g., Aleksandrov, 1998), early stages of the $\mathrm{Fe}-\mathrm{Mg}$ skarn development must have occurred at temperatures $\approx 600{ }^{\circ} \mathrm{C}$. This inference is compatible with temperature values calculated for plagioclase (with evidence of re-crystallisation) - edenite (late) pairs included in host rocks $\left(\leq 600{ }^{\circ} \mathrm{C}\right)$ (Salgueiro, in prep), tracing, quite possibly, the heat peak related to the emplacement/cooling of the magmatic intrusion that triggered the development of the ore-forming system.

The Fe-Mg skarn shows $\Sigma$ REE low values, which can be interpreted as an inherited geochemical characteristic from the protolith subsequently replaced, although the hydrothermal mobility of REE may contribute, at least partly, to explain those totals and some of the features of their normalised concentra- 
tion patterns. Indeed, the relative impoverishment of LREE in the Fe-Mg skarn may be related to the circulation of aqueous-carbonic fluids in reducing conditions like those typically involved in carbonatisation processes. Likewise, the positive $\mathrm{Ce}$ anomaly in sample SD42/126.30 (Fe-Mg skarn) may reflect anoxic conditions, mainly achieved during the deposition of sulphides (quite significant in this sample) in the course of the retrograde stage. Finally, the negative Eu anomalies (Fig. 5B) are indicative of significant interaction with moderately oxygenated hydrothermal fluids (e.g., Michard \& Albarède, 1986).

Following closely the approach proposed by Einaudi et al. (1981) and considering $\mathrm{XCO}_{2} \leq 0.1$, the precipitation of carbonates should have occurred at temperatures below $550{ }^{\circ} \mathrm{C}$, which is compatible with the fact that carbonatisation took place after Mgt I re-crystallisation. Olivine hydration (serpentinisation) in the Fe-Mg skarn should trace a new stage in the evolution of the system, being almost synchronous to the carbonate deposition; despite the serpentine mineral group analysed (Salgueiro, in prep) do not present ideal stoichiometry due to subsequent changes, their deposition must have occurred at temperatures below $420{ }^{\circ} \mathrm{C}$, as reported by Greenwood (1967b, in Einaudi et al., 1981) for similar situations characterised by low partial pressure of volatile and $\mathrm{XCO}_{2}<0.05$. Equivalent temperature (less than $\approx 420{ }^{\circ} \mathrm{C}$ ) conditions can be deduced for the deposition of Py II, Po II and Ccp taking into account their position on the paragenetic sequence. The development of Po II and Py II crypto-crystalline aggregates is interpreted as evidence of abrupt temperature drop following the relative media reduction, $\mathrm{pH}$ decrease and $a\left(S_{2}\right)$ increase.

The formation of prehnite in Fe-Ca skarn suggests that the late stages of hydration took place under conditions of low fluid pressure, which, according to the approach outlined by Einaudi et al. (1981) for similar conditions, should have occurred at temperatures below $400{ }^{\circ} \mathrm{C}$. In this context, the scarcity of Mrc as a result of Po destabilisation, suggests that the decrease in $\mathrm{pH}$ during the retrograde stage (also found in iron-magnesian skarn) was not enough to favour the development of this sulphide. Additionally, the relative rarity of $C c p$ (particularly in the $\mathrm{Fe}-\mathrm{Ca}$ skarn) indicates relative paucity of $\mathrm{Cu}$ in the system since there are no physical-chemical reasons that prevent $C c p$ deposition. Moreover, in this geochemical environment, it is expected that the process had involved mineralising fluids with moderate to high salinity, which is consistent with the relative enrichment in $\mathrm{Na}$ reported by the development of mg-hastingsite/pargasite in the $\mathrm{Fe}-\mathrm{Ca}$ skarn and amphiboles with significant edenitic component in the host rocks (Salgueiro, in prep).

Considering several skarn studies (e.g., Einaudi et al., 1981, Meinert, 1992, 1997, and Pons et al., 2009), the spatially coexistence of two skarn types, as interpreted for the Vale de Pães deposit, may be the result of: 1) an overlapping of iron-calcic skarn on ironmagnesian skarn; 2) heterogeneous fluid/rock ratio due to different protolith features; 3) multiple magmatic source fluids and variable interaction with (different?) host protholith; and 4) differences in progression of equilibrium reactions within the metasomatic front. The geological, mineralogical and geochemical data herein documented for the Vale de Pães deposit, suggest, as a first approach that, with the exception of the first hypothesis, all the others are possible, either plain or modified. However, these hypotheses must be comprehensively examined in detailed studies.

\section{Conclusions}

During formation of the prograde $\mathrm{Fe}-\mathrm{Mg}$ and $\mathrm{Fe}$ Ca skarn mineral parageneses only slight $a\left(\mathrm{O}_{2}\right)$ variations took place; these mineral parageneses are generally oxidised, but in $\mathrm{Fe}-\mathrm{Ca}$ skarn a relatively reduced media can be inferred. The physico-chemical conditions (decrease of $\mathrm{pH}$, temperature and increase in the $a\left(S_{2}\right)$ ) achieved during the retrogradation stage were crucial for sulphide deposition in the $\mathrm{Fe}-\mathrm{Mg}$ skarn, influencing also the observed chemical zonation. In particularly, the circulation of aqueous-carbonic fluids during the late carbonatisation event experienced by the Fe-Mg skarn must have influenced REE mobilization.

Some relevant features (such as the whole-rock $\mathrm{Mn}$ and $\mathrm{Al}$ contents, and $\mathrm{Fa}$ component of olivine), together with the period of Mgt precipitation, suggest that the Fe-Mg skarn is positioned relatively close to the magma source.

\section{References}

Aleksandrov, S.M. (1998). Geochemistry of Skarn and Ore Formation in Dolomites. VSP, Utrecht, Tokyo, 300 pp.

Boynton, W.V. (1984). Geochemistry of the rare earth elements: meteorite studies. In: Rare earth element 
geochemistry (Henderson, P., ed.). Elsevier, Amsterdam, 63-114.

Carvalho, D. (1976). Les gisements de fer du Portugal. In: The iron ore deposits of Europe and adjacent areas (Zitzmann, A., ed.), Commission for the Geological Map of the World. Subcommission for the Metallogenic Map of the World, Hannover, 255-260.

Carvalho, D. \& Oliveira, V. (1992). Recursos minerais. In: Notícia Explicativa da Folha 8: Carta Geológica de Portugal na escala 1:200 000. Serviços Geológicos de Portugal, 81-83.

Degens, E.T.; Wiliams, E.G. \& Keith, E.G. (1958). Application of geochemical criteria [Pennsilvania], part 2 of environmental studies of carboniferous sediments. American Association of Petroleum Geologists Bulletin, 42: 981-997.

Einaudi, M.T. \& Burt, D.M. (1982). Introduction - terminology, classification, and composition of skarn deposits. Economic Geology, 77: 745-754. doi:10.2113/gsecongeo.77.4.745

Einaudi, M.T.; Meinert, L.D. \& Newberry, R.J. (1981). Skarn deposits. Economic Geology, 75th Anniversary Volume: 317-391.

Gromet L.P.; Dymek, R.F.; Haskin L.A. \& Korotev, R.L. (1984). The "North American shale composite": its compilation, major and trace element characteristics. Geochimica et Cosmochimica Acta, 48: 2469-2482. doi:10.1016/0016-7037(84)90298-9

Meinert, L.D. (1992). Skarns and skarn deposits. Geoscience Canada, 10: 145-162.

Meinert, L.D. (1997). Application of skarn deposit zonation models to mineral exploration. Exploration and Mining Geology, 6: 185-208.

Michard, A. \& Albarède, F. (1986). The REE content of some hydrothermal fluids. Chemical Geology, 55: 51-60. doi:10.1016/0009-2541(86)90127-0

Oliveira, V. (1986). Prospecção de minérios metálicos a sul do Tejo. Geociências - Revista da Universidade de Aveiro, 1: 15-22.

Piçarra, J.; Oliveira, V. \& Oliveira, T. (1992). Paleozóico. In: Notícia Explicativa da Folha 8, Carta Geológi- ca de Portugal, escala 1:200000, Lisboa, Serviços Geológicos de Portugal, 25-30.

Pons, J.M.; Franchini, M.; Meinert, L.; Recio, C. \& Etcheverry, R. (2009). Iron Skarns of the Vegas Peladas District, Mendoza, Argentina. Economic Geology, 104: 157-184.

Purtov, V.K.; Kholodnov, V.V.; Afilogov, V.N. \& Nechkin, G.S. (1989). The role of chlorine in the formation of magnetite skarns. International Geology Review, 31: 63-71. doi:10.1080/00206818909465861

Salgueiro, R.M.M. (in prep.). Caracterização e génese das mineralizações de magnetite - sulfuretos de Monges (Santiago do Escoural, Montemor-o-Novo) e ensaio comparativo com as suas congéneres em Orada e Vale de Pães (Serpa - Vidigueira). Tese de Doutoramento (PhD Thesis), Universidade de Lisboa, Lisboa.

Serviço de Fomento Mineiro (1968). Descrição da sondagem, n. ${ }^{\circ} 42$ de Vale de Pães. Serviço de Fomento Mineiro, Relatório Interno, Beja.

Serviço de Fomento Mineiro, 1980 (aprox.), Cartas Geológicas na escala 1:25000, n..$^{\circ} 99$ (Cuba) e $n .^{\circ} 510$ (S. Matias). Serviço de Fomento Mineiro, Beja.

Turekian, K.K. \& Wedepohl, K.H. (1961). Distribution of the elements in some major units of Earth's crust. Geological Society of American Bulletin, 72: 175-192. doi:10.1130/0016-7606(1961)72[175:DOTEIS]2.0.CO;2

Wedepohl, K.H. (1974). Handbook of Geochemistry. Springer-Verlag, Berlin, 374 pp.

Wilde, P; Quinby-Hunt, M.S. \& Erdtmann, B.D. (1996). The whole-rock cerium anomaly: a potential indicator of eustatic sea-level changes in shales of the potential indicator of eustatic sea-level changes in shales of anoxic facies. Sedimentary Geology, 101: 43-53. doi:10.1016/00370738(95)00020-8

Zharikov, V.A. (1970). Skarns. International Geology Review, 12: 541-559, 619-647, 760-775. doi:10.1080/00206817009475262

Recibido el 3 de diciembre de 2009 Aceptado el 18 de marzo de 2010 Publicado online el 19 de mayo de 2010 